\title{
PRODUCTION, USAGE AND POTENTIAL PUBLIC HEALTH EFFECTS OF ALUMINUM COOKWARE: A REVIEW
}

\author{
Okunola A. Alabi* and Yetunde M. Adeoluwa
}

Department of Biology, Federal University of Technology, Akure, Ondo State, Nigeria.

Received $26^{\text {th }}$ December, 2019, Accepted $1^{\text {st }}$ April, 2020

DOI: 10.2478/ast-2020-0003

*Corresponding author

Okunola A. Alabi E-mail: alabiokunola@yahoo.com; oaalabi@futa.edu.ng

Tel: $+234-8034416394$

\begin{abstract}
The ingestion of aluminum from food containers such as cookware, cans, utensils and wrappings and its subsequent release into the environment is a growing public health concern. Aluminum is widely used in manufacturing cookware due to its malleability, high heat conductivity, light weight, durability, availability and affordability. This paper therefore gives a review of most relevant literatures on the benefits and risks of the various types of aluminum cookware in use, the composition and the public health effects of aluminum ingestion. Studies that reported the leaching of aluminum from cookware into food and environmental effects of aluminum leaching were also reviewed. In the developing countries, aluminum cookwares are produced from scrap metals and has been reported to leach harmful substances including heavy metals such as: nickel, arsenic, copper, cadmium, lead, and aluminum into cooked food. Several factors have been reported to increase the rate of leaching of metals from aluminum cookwares. Exposure to metals from aluminum cookware and the public health effects have not been well studied, hence, our recommendation for more studies to elucidate the health effect of this practice. This review also presents measures that can limit exposure to the risks that may arise from the use of aluminum cookware.
\end{abstract}

Keywords: Aluminum cookware, Leaching, Public health, Heavy metals, Toxicity 


\subsection{Introduction}

Aluminum is the third most abundant element in nature (Hassan et al., 2008). It is the most abundant metal which occurs naturally in silicates, cryolite and bauxite rock. It is a good conductor of heat which makes it a great choice for cookware with its thermal conductivity sixteen times greater than that of stainless steel. Pure aluminum is nevertheless very soft and it is therefore often mixed with other metals and elements like silicon, zinc, copper, magnesium, manganese and lithium to form alloys which are stronger and harder and hence of increased versatility (ATSDR, 1999; Wagner, 1999). The tensile strength of some copper-aluminum alloys can exceed that of mild steel by as much as $50 \%$ (Wagner, 1999).

Aluminum metal and its alloys are used widely in building construction such as siding and roofing, doors, windows and also in transportation to manufacture automobiles and aircraft. It is used to produce storage and packaging materials like beverage cans and also for electrical equipment, cookware, decorations, road signs, fencing, foil, corrosion-resistant chemical equipment, solid fuel rocket propellants, explosives, dental crowns and jewelry (Krewski et al., 2007). Aluminum is also a component of many items used daily such as over-the-counter medications which include but are not limited to antacids, buffered aspirins, anti-diarrheal products and body care products (Mohammad et al., 2011). Aluminum is used in making home cooking utensils due to its malleability, making it easy to be bent or pressed into several shapes (Odularu et al., 2013). These utensils have high heat conductivity and thus cook food evenly. They are light weight, easy to clean, durable and affordable as a result of easy availability of aluminum. An assortment of aluminum cookware and utensils are in use all over the world, some of which are locally made, uncoated and non-anodized with each type having its own benefits and risk factors (Table 1). Aluminum cookware is widely used throughout the developing world (Bergkvist et al., 2010; Al Zubaidy et al., 2011; Al Juhaiman 2012).

\section{Types of Cookware}

There are different types of cookware in use all over the world which are made from variety of materials ranging from clay, ceramics, glass, to metals like gold, silver, copper, brass, bronze, cast iron, steel, stainless steel aluminum alloys and food grade plastics. These assortments of cookware have their own advantages and disadvantages depending on the type of material used in their production (Table 2). Leaching of materials from any type of cookware is also dependent on the type of material used in their manufacture and the cooking temperature.

\section{Production of Aluminum Cookware}

Aluminum cookwares are manufactured using heat processing similar to the cast iron skillets. It involves a casting process requiring melting metal which is then poured into a cast. Scrap metals including waste engine parts, vehicle radiators, lead batteries, computer parts and other materials are the primary source materials used by local artisans in manufacturing forged aluminum cookware which pose a significant risk by leaching of multiple metals during cooking (Weidenhamer et al., 2016).

In the developing countries, the pot makers depend on aluminum products like broken spoons, plates, old aluminum pots, cans and other containers that have been used and thrown away which they pick up from the streets, gutters and dust bins. The potters also go to bicycle repairers, iron benders and mechanic workshops to acquire used aluminum parts of generators, motorcycles and vehicles (Abubakar, 2011). The major tools and equipment used in the melting section by these artisans are air blowing machine, wheel, fire mouth, iron pot (old gas container of refrigerator), pincers, hammer, metal rods, wooden rods and knives (Oke and Oyeniyi, 2013). The effort of two or more people is required in the production process. With the aid of a pipe, the blowing machine is permanently linked to a fire mouth powered by burning charcoal, with the iron pot containing the aluminum material placed on top of it (Figure 1). The aluminum material melts to liquid form in this process. One or two pieces of dry cell battery are added to it to enable the impure materials to float and be removed from the pot (Okunna, 2004). When the hot liquid is ready, it is poured into a clay mold to form a cast and the cast is allowed to cool down for at least five minutes before the aluminum pot is removed from the mold (Figure 2). A metal file is then rubbed through the body of the pot to get a fine finish (Figure 3) (Suleiman, 2011).

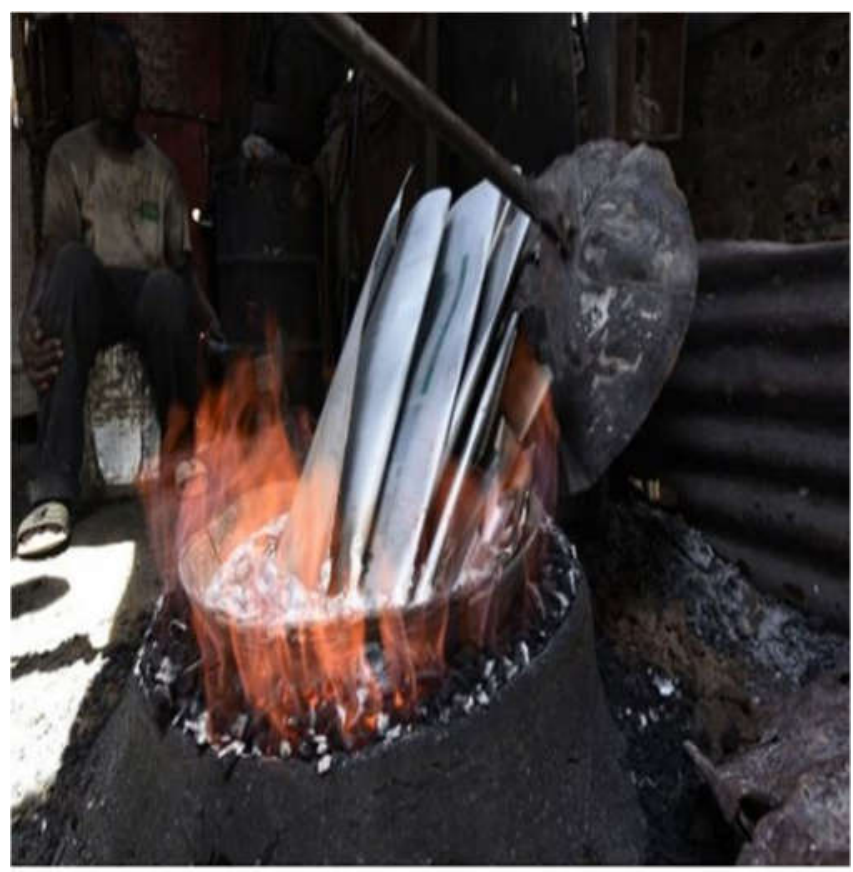

Figure 1: Melting of aluminum plates to produce cooking pots. Source: The Epoch Times, 2017 


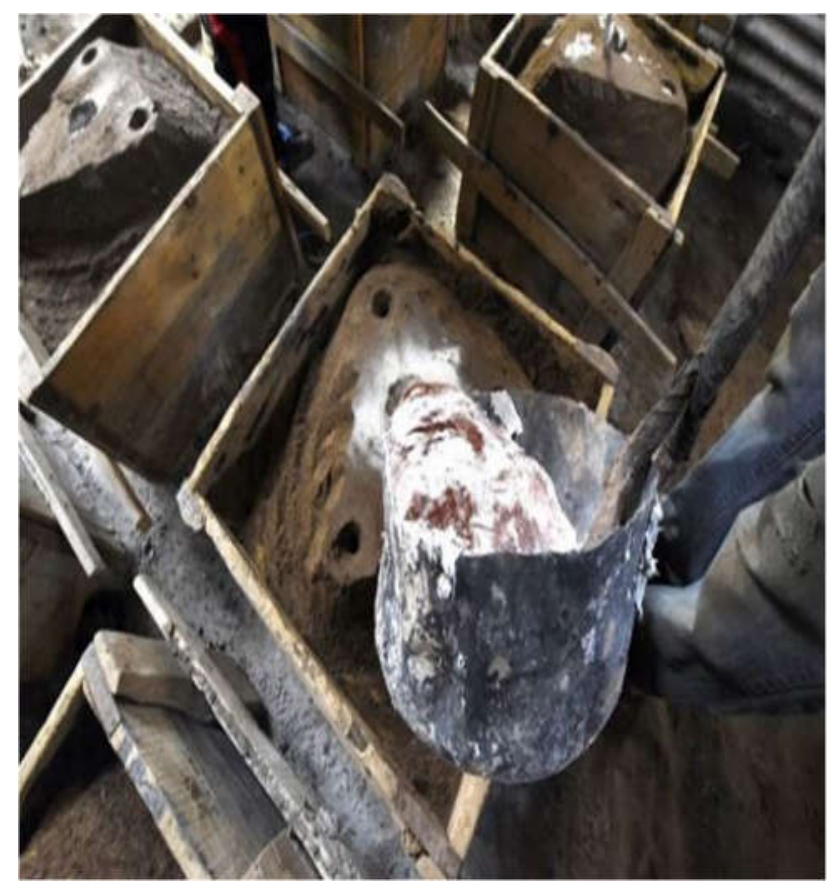

Figure 2: Pouring of melted aluminum into a mold to produce cooking pots.

Source: The Epoch times, 2017.

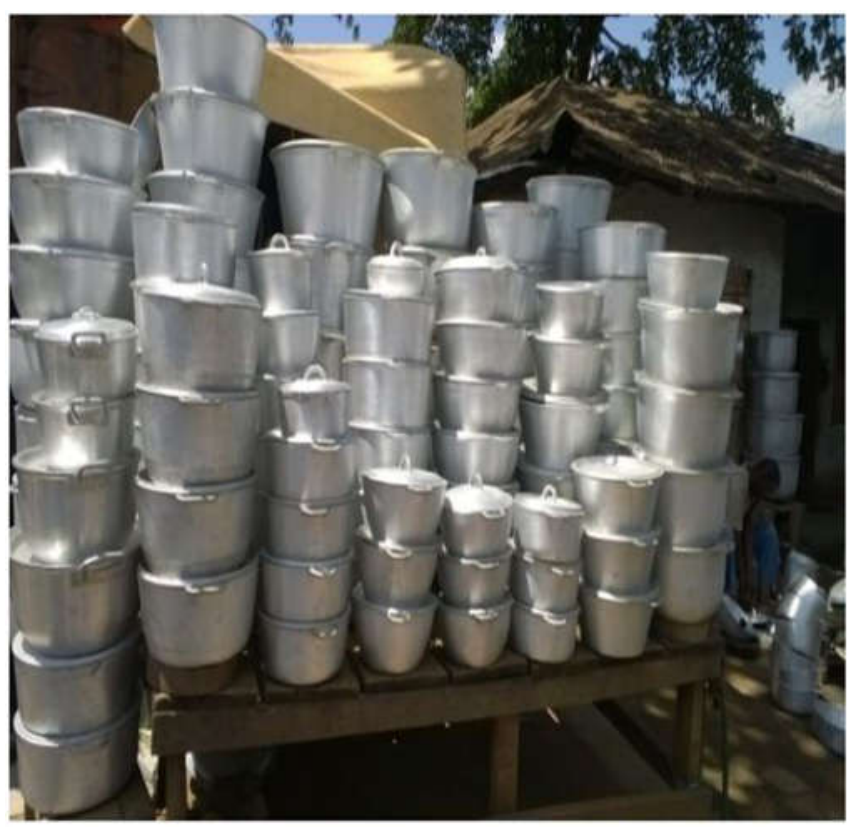

Figure 3: A file photo of aluminum pots made from scrap metal in a market in Cameroon, Africa. Source: The Epoch times (2017)
On a more refined industrial scale, the process of manufacturing aluminum involves various steps which include: blanking, punching and piercing to cut out portion of metal, deep drawing to shape and size metal sheet relative to the required design, metal forming by spinning along the die surface to get desired profile. This is followed by bulging process to expand metal, beading and curling to roll metal under a die to create ring of material along the edge, coining or embossing to reduce thickness to maximum of up to thirty percent of base thickness, extruding where a pilot hole is pierced, and punch is pushed through to expand the metal and grow in length. Finally, necking and rib forming to create an inward or outward protrusion of metal on surface trimmer to remove excess metal to get the finished part. The utensils are anodized, polished and inspected. The finished utensils of various sizes are bunched into set of utensils and packed for dispatch. The application of handles onto copper and aluminum pots is carried out by nailing them onto the body of the pot with particularly resistant alloy rivets (AG5) or with rivets made from the same metal as the container (Guidetti and Simonetti, 2000).

A new development in the manufacturing procedures of cookware is coating internally with a film of food-grade plastic material, polytrifluoroethylene (PTFE), which involves combining aluminum with non-stick materials by subjecting anodized aluminum to a polymer infusion process, thus conferring an anti-stick property; such that it allows less fat to be used in cooking and makes it easier to wash. Various cooking utensils have nonstick coating which is applied to the cookware in a furnace and industrial oven. The processing involves an initial phase of preparation of the metal onto which the coating is to be applied, cleaning or removal of grease and sanding. Subsequently is the application phase, normally of more than one layer, until a thickness is reached which allows it to perform to its maximum in terms of resistance against friction but also in terms of duration over time (Guidetti and Simonetti, 2000). This coating in aluminum cookware is also meant to minimize leaching of metals into cooked foods, however, this gets worn out by scratching as time goes on.

\section{Recycling of Aluminum and the production of aluminum cookware}

Aluminum recycling is the method of reusing scrap aluminum and other metals to make new products after its original production. Many of the aluminum cookware and cans currently in use contain some amount of recycled metals while others are exclusively made of recycled metals. The importance of scraps as a source of aluminum supply continues to increase from the start of the aluminum industry. Domestic primary aluminum production accounted for over forty percent of the world's aluminum production after the Second World War. Primary aluminum was manufactured in forty three countries in the year 2000, with the United States producing about fifteen percent of the twenty four million tons of production, having metals recovered from scrap making up around thirty five percent of this local supply of aluminum (Patricia, 2000). The process of producing recycled aluminum into new products involves different stages like separation of the metals, cleaning, melting, forming into different shapes, cooling, refining and polishing. This process is energy-saving, inexpensive and 
considered sustainable, as it significantly reduces the level of greenhouse gas emission when compared to the process used to make entirely new aluminum products. About thirty five percent of all aluminum materials manufactured in the United States are from old recycled scrap (Schlesinger, 2006). Aluminum cookwares manufactured from scraps has been identified as a potential source of heavy metals especially lead and arsenic poisoning in developing countries (Weidenhamer et al., 2016).

\section{Constituents of Aluminum Cookware}

\section{Lead}

Lead is a heavy metal with a high toxicity even at very low exposure levels. It has acute and chronic effects on health and the environment. Lead is not degradable in nature and will therefore remain in circulation once released to the environment. A source of lead exposure that has largely been overlooked is locally-made aluminum cookware (Bergkvist et al., 2010). Despite the removal of lead additives from gasoline several years ago, many recent studies reports the widespread persistence of high blood levels especially in developing countries (El Desoky et al., 2013, Kalra et al., 2013, Kapitsinon et al., 2015). Artisanal aluminum cookware may be a major contributor to lead poisoning (Weidenhamer et al., 2014) because it is mostly made from scrap metals like car parts including lead batteries as additive. The potential for lead to leach from this type of cookware has been reported and estimated to be as high as $260 \mu \mathrm{g} / \mathrm{serving}$, indicating a potential health hazard (Al Juhaiman, 2010; 2012; 2016). At Ashland University in Ohio, researchers and the nonprofit Occupational Knowledge International studied forty two pots from ten developing countries, and reported that more than one-third posed a risk of lead exposure. The highest level was in Vietnam, where one pot released 2,800 times more lead than California's maximum allowable dose level of $0.5 \mu \mathrm{g} /$ day (Weidenhamer et al., 2016). WHO has established a provisional tolerable weekly intake of $25 \mu \mathrm{g} / \mathrm{kg}$ of body weight for lead (equivalent to $3.5 \mu \mathrm{g} / \mathrm{kg}$ of body weight per day).

\section{Arsenic}

Arsenic is another heavy metal that poses threat to both human health and the environment. Arsenic is found in contaminated dusts, water, soil, containers and agrochemical wastes (Nriagu and Azcue, 1990). Studies by Weidenhamer et al. (2016) reported that measureable levels of arsenic was generated by 23 (55\%) aluminum cookwares from the Philippines, with a concentrated level of $10 \mu \mathrm{g} / \mathrm{serving}$ in one pot. Also in Bangladesh, a country with serious arsenic poisoning due to contaminated groundwater, all four cookware items studied were observed to leach arsenic up to a concentration of $6 \mu \mathrm{g} /$ serving (Uddin and Huda, 2011; WHO, 2011a). Arsenic in aluminum cookware can be traced mostly to the scrap metals used in the production of aluminum cookware.

\section{Cadmium}

Cadmium is another heavy metal with high toxicity and it accumulates in the human body especially the kidney (NCM, 2003). Cadmium oxides are used in the chemical industry for electroplating in electric batteries, as stabilizers for plastics, and pigments for enamels. Rechargeable batteries and special alloys produced from cadmium also form a vital part of the scraps used in the production of aluminum cookware. Studies by Liangbo et al. (2017) reported the migration of cadmium into food from aluminum alloy pots during cooking at high temperatures, the rate of which increases with the cooking time. Also, when the pots were used to heat $15 \%$ ethanol under high temperature, the released amount of cadmium increased drastically (Liangbo et al., 2017).

\section{Copper}

Metallic copper is flexible, ductile and a good conductor of thermal and electrical energy. Copper is used to make cooking utensils, electrical wiring, coins, pipes, faucets, fittings, building tools and for other commercial uses because of its versatility. It is also present in munitions, alloys (brass, bronze), coatings, fungicides, insecticides and wood preservatives. The main source of copper exposure in developed countries is through food and water (NCM, 2003). Copper is also a constituent of aluminum cookware that can leach into food during the process of cooking leading to elevation of the normal dietary intake range. Omar et al. (2015) studied the bioavailability of heavy metals in rice cooked with aluminum cooker using in vitro digestion model and inductively coupled plasma optical emission spectrometry (ICP-OES), the result showed that the cooked rice contained Copper at a concentration of $1.1 \pm 0.1 \mathrm{mg} / \mathrm{kg}$. Although copper can be considered essential at low concentration, it is usually toxic at high levels (Rignell et al., 2009; Chen et al., 2009).

\section{Nickel}

Nickel is an abundant, strong, lustrous, silver-white metal which finds progressively more applications in modern technologies. It is very ductile and malleable, resistant to corrosion making it excellent for its choice as one of the metals alloys for manufacturing cookware. Most of the nickel produced is used for manufacturing stainless steel, nickel alloys, and nickel cast iron that include objects, such as, kitchen utensils, electrical equipment, tools, coins, machinery, armaments and jewelry. Nickel compounds are also used for electroplating, electroforming, nickel-cadmium alkaline batteries, dye mordant, catalysts and electronic equipment (Aleksandra and Urszula, 2008). Non-occupational sources of nickel exposure for the general population include mainly drinking water and food. The daily consumption of nickel through food is estimated at $0.15-0.7 \mathrm{mg} /$ day (CAC, 1995). Several researchers have reported that some quantities of nickel are always transferred into cooked food (Sunderman, 1989; CAC, 1995; Agarwal et al., 1997; Berg and Petersen, 2000). Ogidi et al. (2017) reported an increased level of nickel in tomatoes sauce which is attributed to leaching of the metal from the household aluminum cookwares used.

\section{Fluoropolymer Coating}

Fluoropolymers are the polymer materials containing fluorine atoms in their chemical structures. They are high-performance plastic materials used in strong chemical and high-temperature environments, in defense-related industries, electronics, automotive, aerospace, and telecommunications (Smart et al., 1995). About 85 percent of fluoropolymers are used in industrial applications like wire insulation for computer networks, automotive fuel hoses, semi- 
conductor manufacturing equipment among others while the other fifteen percent is used in consumer products such as nonstick cookware and weather- and chemical-protective fabrics (Salamone, 1996). There are two types of fluoropolymer materials, which are the perfluoropolymers and partially fluorinated polymers. In partially fluorinated polymers, all the hydrogen atoms in the analogous hydrocarbon polymer structures are replaced by fluorine atoms while in perfluoropolymers there are both hydrogen and fluorine atoms in the polymer structures along with other elements in selected cases, such as polyvinylidenefluoride and polychlorotrifluoroethylene. Fluoropolymers have outstanding properties such as low surface energy, excellent chemical resistance, weather stability, low coefficient of friction, and low dielectric constant. These properties come from the special electronic structure of the fluorine atom, the stable carbonfluorine covalent bonding, and the unique intramolecular and intermolecular interactions between the fluorinated polymer segments and the main chains (Scheirs et al., 1997), hence their choice as a suitable film of coating on the surface of anodized aluminum in the manufacture of non-stick Aluminum cookware.

\section{Human exposure to aluminum}

There is widespread use of cheap aluminum cookware in many countries (Osborn, 2009) and as such evaluating the extent of metal exposures from this source and proffering solutions is of utmost importance (Weidenhamer et al., 2016). An average of $30 \mathrm{mg}$ of aluminum is daily ingested through food, water and drugs (Mohammad et al., 2011). The daily intake of aluminum was reported to be $18-36 \mathrm{mg}$ per day prior to 1980 . WHO in 1989 put the provisional tolerable weekly intake of aluminum per kilogram per bodyweight at $7 \mathrm{mg}$ (Al Juhaiman, 2012). Consequently, a person with a weight of $60 \mathrm{~kg}$ should not consume more than $60 \mathrm{mg}$ of aluminum per day (Odularu et al., 2013). The primary source for aluminum intake under biological conditions is food (Yokel and McNamara, 2001). The main sources of aluminum in the diet include artificially added aluminum (in grain products, processed cheese and salt) and high dosages of naturally occurring aluminum (in tea, herbs and spices). Because of the factors of natural content of aluminum in food and its reaction with storage materials and cookware, aluminum concentration in food is not always constant. The air we breathe is a major contributor to aluminum exposure. This is influenced by activities like workplace exposure (Polizzi et al., 2002) and habits such as smoking cannabis, cocaine and heroin (Exley et al., 2006). Exposure to aluminum is almost impossible to avoid because of the extensive presence of this metal ion both in foodstuffs and in the atmosphere.

Apart from other sources of dietary aluminum, aluminum cookware is considered to be a likely source of aluminum leaching into beverages, water and food under diverse experimental conditions modified by varying the levels of citrate, chlorides, fluorides, $\mathrm{pH}$ and acetate (Al Zubaidy et al., 2011). Reports have shown that acidic food like tomatoes and simple foods like oils and cereals oxidize aluminum alloys and there is a concern of the absorption of aluminum from cookware (Semwal et al., 2006). Leaching is most likely to occur in cooking utensils due to factors such as temperature and $\mathrm{pH}$ during cooking and the release of the ions as the years increase (Odularu et al., 2013). Several reports confirmed that the leaching of aluminum is extremely dependent on $\mathrm{pH}$, temperature and the presence of complexing agents from the alloys used in making the aluminum cookware (Semwal et al., 2006; Dabonne et al., 2010; Zubaidy et al., 2011; Odularu et al., 2013; Weidenhamer et al., 2014, 2016). Aluminum displays an inert behavior in aqueous solutions because of the protective compact $\mathrm{Al}_{2} \mathrm{O}_{3}$ film on its surface. The solubility of this protective film nonetheless increases in acidic and alkaline medium. The leaching of aluminum in aqueous solutions can be explained by the chemical reaction below which occurs on the surface of the aluminum cookware, the released free aluminum ions then reacts with organic acids and other compounds found in food.

$$
\mathrm{Al}_{2} \mathrm{O}_{3}+6 \mathrm{H}^{+}=2 \mathrm{Al}^{3+}+3 \mathrm{H}_{2} \mathrm{O}
$$

The use of aluminum cookware for cooking offers a significant route for the entrance of aluminum metal into food and subsequently into humans that consume such foods (Adelkhani et al., 2009). Aluminum present in cookware especially in the case of acidic dishes such as tomato sauce can expose man to the consumption of high quantities of aluminum. Several studies showed that the leaching process increases by the addition of salt and citric acid to aluminum cookware (Karbouj, 2007; Mohammad et al., 2011) and with the increasing fluoride content in cooking water (Amarasooriya and Dharmagunawardhane, 2014). In recent times, wrapping meat and fish prior to oven cooking has become a common practice which has led to the excessive consumption of aluminum leached from aluminum foil with potential health risk. Studies on leaching of aluminum from aluminum foil using meat of various types (chicken, beef, mutton, water buffalo, and turkey) in different food solutions of tomato juice, citric acid, apple vinegar, salt, and spices packed with aluminum foil and cooked in the oven at different temperatures and time periods indicate that cooking increases the aluminum concentration in white and red meats, and in poultry having aluminum leaching values ranging between 59.83 220.20 mg/kg (Ranaua et al., 2001; Turhan, 2006). For grilled and baked fish fillets wrapped in aluminum foil, the leaching of aluminum depends on the duration of grilling, food $\mathrm{pH}$ value, heating temperature, composition and presence of any other substances (Turhan, 2006). Other studies report that aluminum is found to leach out from the foil in different stimulants, particularly in distilled water as well as acidic and alkaline media. Leaching of aluminum is found to be significantly higher in acidic and aqueous media compared to alcoholic and saline media. Conditions of higher temperature also increase the rate of movement of aluminum in acidic and aqueous media (Deepa and Padmalatha, 2013). The fat content in meat, in addition to the cooking process, has an effect on the leaching of aluminum with raw chicken and turkey breast meat having higher amounts of aluminum than the raw chicken and turkey leg meat, respectively. The amount of leaching are found to be high in acidic solutions and higher with the addition of spices (Bassioni et al., 2012). 
Table 1: Types of Aluminum Cookware, their characteristics and potential health risks.

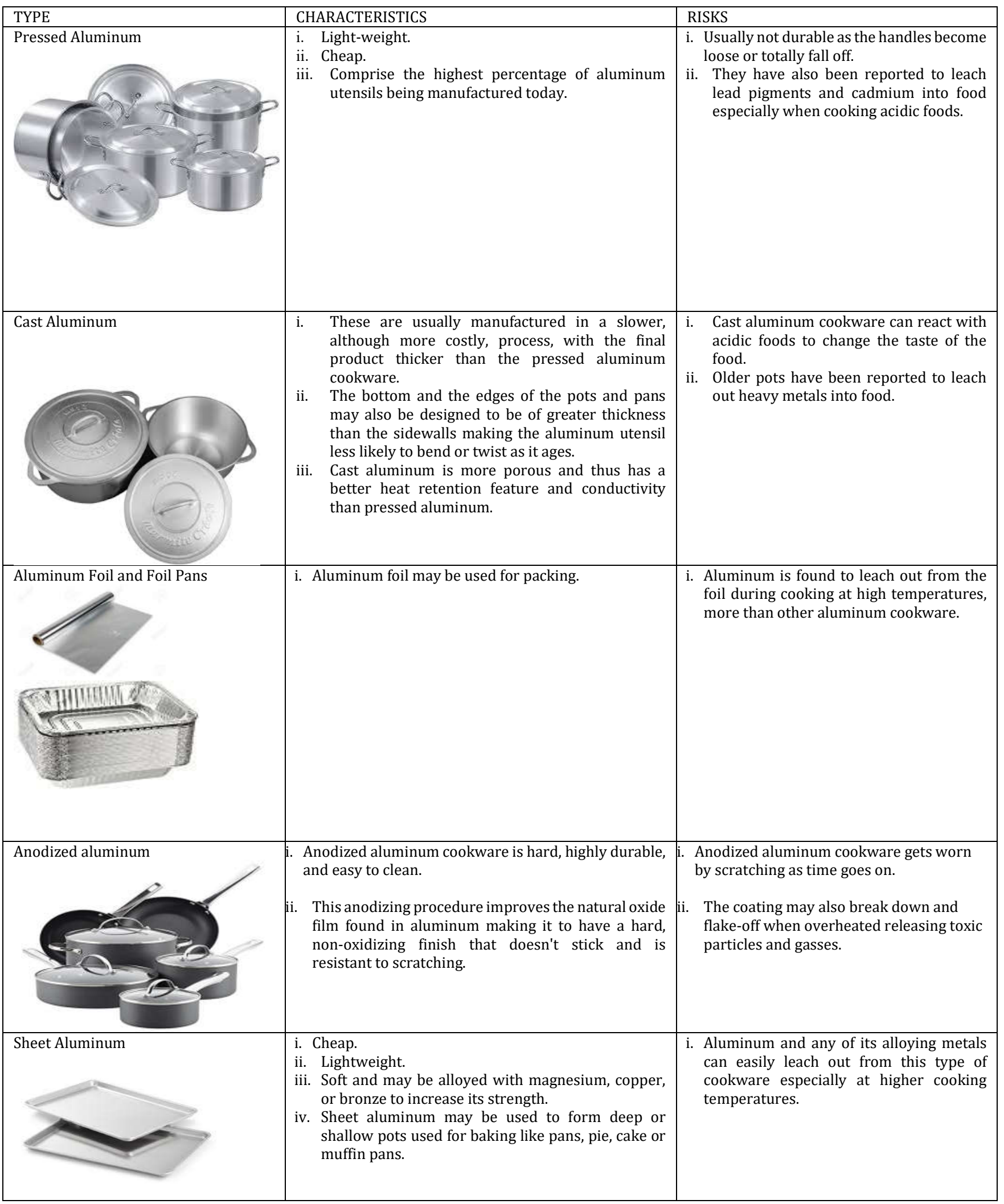

Source: Guidetti and Simonetti, 2000. 
Table 2: Different types of cookwares, their advantages and disadvantages.

\begin{tabular}{|c|c|c|}
\hline TYPE & ADVANTAGES & DISADVANTAGES \\
\hline Aluminum Cookware & $\begin{array}{l}\text { i. Recyclable } \\
\text { ii. Lightweight. } \\
\text { iii. Thermally responsive. } \\
\text { iv. Easy to clean. } \\
\text { v. Fairly inexpensive. } \\
\text { vi. Energy saving. } \\
\text { vii. Hygienically safe. } \\
\text { viii. Resistant to thermal shock, corrosion and scratching. } \\
\text { ix. Quality-price ratio is fair. }\end{array}$ & $\begin{array}{l}\text { i. The metal has consistently been placed in the top } 200 \text { health- } \\
\text { jeopardizing toxins by the Agency for Toxic Substances and } \\
\text { Disease Registry (ATSDR) at the U.S. Department of Health and } \\
\text { Human Services. } \\
\text { ii. During cooking, some aluminum especially from worn or pitted } \\
\text { pots and pans may dissolve into food. } \\
\text { iii. The longer food is cooked or stored in aluminum, the greater } \\
\text { the amount of aluminum that gets into food. } \\
\text { iv. Leafy vegetables and acidic foods such as tomatoes and citrus } \\
\text { products, absorb aluminum the most. } \\
\text { v. Salty water or food can pit aluminum cookware, making older } \\
\text { pots a possible source for trace amounts of substances like } \\
\text { arsenic and fluorides. }\end{array}$ \\
\hline Copper cookware & $\begin{array}{l}\text { i. Conducts heat well, making it easy to control cooking } \\
\text { temperatures. }\end{array}$ & $\begin{array}{l}\text { i. High level of copper leaching can occur when acidic foods are } \\
\text { prepared in copper cooking utensils, which can cause chemical } \\
\text { toxicity and illness. }\end{array}$ \\
\hline Cast iron cookware & $\begin{array}{l}\text { i. Thick and dense which gives even and high heating } \\
\text { capacity. } \\
\text { ii. Releases some iron (essential nutrient) into food which } \\
\text { is beneficial to the body. } \\
\text { iii. Retains heat after the element is turned off. This is a } \\
\text { good attribute for slow cooking and keeping food hot for } \\
\text { a longer period of time. }\end{array}$ & i. May rust if not properly maintained. \\
\hline $\begin{array}{l}\text { Ceramic, Glass, Crock Pot, } \\
\text { Terra Cotta cookware }\end{array}$ & $\begin{array}{l}\text { i. } \text { Easily cleaned. } \\
\text { ii. Can be heated to fairly high temperatures. } \\
\text { iii. Ceramic cookware is glazed with a form of glass to resist } \\
\text { wear and corrosion. } \\
\text { iv. Some glass containers are microwave safe. }\end{array}$ & $\begin{array}{l}\text { i. Minor components used in making, glazing, or decorating } \\
\text { ceramic and glassware such as lead, pigments or cadmium may } \\
\text { cause potential health risks. } \\
\text { ii. Lead, pigments and cadmium may leach into food especially } \\
\text { when cooking acidic foods. }\end{array}$ \\
\hline $\begin{array}{l}\text { Stainless steel pots and } \\
\text { pans }\end{array}$ & $\begin{array}{l}\text { i. Saves energy significantly. } \\
\text { ii. Cooks food excellently for very long period over low } \\
\text { heat and light. } \\
\text { iii. Resistant to thermal shock, corrosion and scratching. } \\
\text { iv. Inexpensive. } \\
\text { v. Has cooking surface with less toxic materials than } \\
\text { aluminum or non-stick coatings } \\
\text { vi. Can be used at high heat. } \\
\text { vii. The surface is sturdy, strong, and scratching and } \\
\text { corroding resistant. } \\
\text { viii. Long-lasting, stable and less susceptible to leaching } \\
\text { ix. Considered one of the best and safest choices when } \\
\text { choosing cookware. }\end{array}$ & $\begin{array}{l}\text { i. The metals present in the alloy used in stainless steel can be } \\
\text { released into food. These metals include nickel, molybdenum, } \\
\text { titanium, aluminum, chromium and carbon steel may produce } \\
\text { health effects. }\end{array}$ \\
\hline Gold Cookware & $\begin{array}{l}\text { i. Has excellent heat conducting capacity and thus saves } \\
\text { energy. } \\
\text { ii. Resistant to thermal shock, corrosion and scratching. } \\
\text { iii. Bacteriostatic. } \\
\text { iv. Excellent for very long cooking over a low heat. }\end{array}$ & i. Highly expensive \\
\hline $\begin{array}{l}\text { Teflon } \\
\text { (Polytetrafluoroethlyene) } \\
\text { coated cookware }\end{array}$ & i. Non-stick & $\begin{array}{l}\text { i. Can heat up to } 430^{\circ} \mathrm{C} \text { within } 5 \text { minutes if left unattended. } \\
\text { ii. Produces toxic fumes when heated with high heat which causes } \\
\text { an illness in humans known as polymer fume fever. } \\
\text { iii. Scratch easily and may release trace amounts of inert plastic into } \\
\text { the food when cooked. } \\
\text { iv. May contain perfluorooctanoic acid (PFOA), a chemical used to } \\
\text { bond the non-stick coating to the pan. PFOA has been shown to } \\
\text { cause cancer, low birth weight, and a suppressed immune system } \\
\text { in laboratory animals exposed to high doses. }\end{array}$ \\
\hline Plastic coated wares & $\begin{array}{ll}\text { i. } & \text { Lightweight. ii. Hard to break. } \\
\text { iii. Suitable for use with microwave. }\end{array}$ & $\begin{array}{l}\text { i. At high temperature, food especially fatty and oily food may } \\
\text { absorb some of the plasticiser. }\end{array}$ \\
\hline Bamboo steamers & $\begin{array}{l}\text { i. Non-reactive. } \\
\text { ii. Considered safe and not harmful to health. }\end{array}$ & i. Chipped bamboo steamers may cause physical hazard. \\
\hline Silicone baking wares & $\begin{array}{l}\text { i. Colorful. ii. Lightweight. iii. Non-stick. iv. Stain-resistant. } \\
\text { v. Hard-wearing. vi. Cools quickly. vii. Tolerates extreme } \\
\text { temperature. viii. Freezer, refrigerator, microwave, } \\
\text { dishwasher and oven safe. ix. No known health hazard. } \\
\text { x. Does not react with food or beverages. xi. Does not } \\
\text { produce fumes when heated. }\end{array}$ & i. $\quad$ Relatively expensive \\
\hline
\end{tabular}

Source: Guidetti and Simonetti, 2000. 


\section{Public health effects of cooking with aluminum cookware}

There is limited information about the direct public health effects of cooking with aluminum cookware, however, there is increased public health concern as a result of consumption of aluminum and other metals from cookware. Thirty-five metals are of concern to human health according to reports by International Occupational Safety and Health Information Centre, and about one billion people globally suffer from some form of diseases that are linked to these metals (WHO, 2011a). Although many of these metals play important roles in all life forms, some of them can have undesirable effects at high concentrations. For example, arsenic, copper, iron and nickel are considered vital at low concentrations but are highly toxic at high levels (Ogidi et al., 2017). High concentrations of aluminum have been discovered in the brain tissue of patients with Alzheimer's disease, dialysis encephalopathy and Parkinson disease (Tabrizi, 2007). The toxicity of aluminum particularly to the aged and to people with kidney failure has also been reported (Soni et al., 2001). Aluminum salts can be absorbed by the gut and concentrated in many human tissues especially brain, bone and parathyroid. Bone and liver are the tissues most commonly affected by increased absorption and/or decreased clearance of aluminum. The growth rate of human brain cells slows down with the presence of aluminum. This decrease in growth rate becomes more evident at higher aluminum concentration (Kim, 2001). Exposure to aluminum can cause male reproductive toxicity, with high concentrations of aluminum in the spermatozoa and seminal fluid of humans reported to affect sperm viability and motility, testicular aluminum accumulation, structural changes in the testis such as formation of giant cells, necrosis of spermatocytes and spermatids and a substantial decline in fertility (Chinoy et al., 2005; Yousef et al., 2007). This reproductive toxicity is as a result of different mechanisms which may include interfering with spermatogenesis and steroidogenesis, inducing oxidative stress, damaging cell signaling, disturbing the blood-testis barrier, promoting lipid peroxidation and affecting the endocrine system (Pandey and Jain, 2015). Oxidative damage and testicular toxicity triggered by aluminum can be linked to the decline in acetyl cholinesterase (AChE) activity of the testis. Aluminum ion can inhibit different metabolism processes in humans by competing with other ions such as magnesium, calcium, iron, phosphorus, and fluoride in various chemical reactions. Malluche (2002) reported that aluminum is connected with anemia, osteomalacia and neurologic syndrome.

Weidenhamer et al. (2016) also reported that cookware items manufactured by local artisans pose a significant threat to health from leaching of various metals during cooking. From cooking alone, potential lead exposures were estimated to be as high as $250 \mu \mathrm{g}$ per serving, with a severe potential toxicity to health (Weidenhamer et al., 2016). Lead can cause wide range of biological effects in humans which is dependent on the level and duration of exposure. These effects may include inhibition of enzymes, production of marked morphological changes and death. The effect of lead on the central nervous system is of particular concern for the general populace. Lead exposure may result in damage to the learning capacity, high blood pressure, decline in development of intellectual capability and also cardiovascular diseases (Goyer, 1986). For neurological, metabolic and behavioral reasons, children are more vulnerable to the effects of lead than adults. Epidemiological studies suggest that low level exposure of the foetus and developing child may lead to reprotoxic effects affecting neuropsychological development. Lead is identified to cause kidney damage. It also has reproductive effect in male by altering sperm morphology and count while in female, some adverse pregnancy outcomes have been attributed to lead. Absorbed lead is rapidly taken up into blood and soft tissue, followed by a slower redistribution to bone (NCM, 2003). Lead is accumulated in the bone during much of the human life span and may serve as an endogenous source of lead that may be slowly released over several years after the exposure stops (WHO, 1995).

Furthermore, simulated cooking in the laboratory released significant concentration of other metals like cadmium, copper and arsenic from aluminum cookwares (WHO, 2011b). It is an established fact that arsenic is toxic in chronic and acute state. High exposure of arsenic is unevenly distributed into the kidney, lungs, liver and the skin causing arsenicosis, which has not been satisfactorily proven to have cure, while chronic poisoning of arsenic can be reconverted into a less toxic form by the liver and excreted via urine (Caroli et al., 1996). Cadmium which can also be present in scraps and other metals used in manufacturing aluminum cookware has a remarkably extended halflife in the human body when ingested, and permanently accumulates in the human body, especially in the liver, kidney and lung. It is more lethal than other heavy metals because it alters biological systems, even at a much lower dose (Nordberg et al., 2007). Only a small portion of nickel ingested is absorbed by the body. Consumption of even small quantities of orally ingested nickel from foods rich in nickel or food and drinks polluted through nickel-containing utensils may however lead to an outbreak of eczema in some patients with certain types of nickel dermatitis (Elinder, 1986). Adverse health effects after oral exposure to nickel occur only when the levels exceed many times the normal level of the metal occurring in food or drinking water and are particularly rare cases.

\section{Mitigation against leaching of metals from aluminum cookware}

A progressive shift to the use of anodized aluminum cookware should be encouraged to minimize the leaching of aluminum into cooked food. Anodization of aluminum cookware provides a surface that is far more resistant to corrosion and leaching (Sekheta et al., 2010). Anodized aluminum cookware is produced by combining aluminum with nonstick materials which is achieved by coating internally with a film of food-grade plastic material, such as polytrifluoroethylene. The anodized aluminum is subjected to a polymer infusion process which confers an anti-stick property and also makes the cookware resistant to scratching. The source of alloying metals in the manufacture of aluminum cookware should also be properly screened and regulated to minimize exposure to heavy metals that may likely leach from the cookware during the process of cooking. For cookware that are usually produced from scraps, these scraps should be properly tested and screened with analyzers to eliminate metals with potential toxic effects to public health. Furthermore, since the probability of leaching occurrence in cookware is largely dependent on factors of temperature and $\mathrm{pH}$, as well as the release of ions as the cookware 
ages, the prolonged usage of these cookware should therefore be discouraged and cooking acidic foods in them should also be avoided. There is need for public enlightenment on the potential health implications of cooking with aluminum cookware especially in the developing countries where scrap metals are the main source of materials used in the production of aluminum cookware. Education on the toxicity associated with long time use of aluminum cookware is also necessary to discourage the populace from prolong use of aluminum cookwares in homes.

There is need for more studies into the potential toxicity of cooking with aluminum cookwares. This will provide more scientific explanation to the health effect of using aluminum cookwares and probably help in the legislation to protect the populace.

\section{Conclusion}

A collection of aluminum cookware and utensils are in use all over the world, a lot of which are locally made, uncoated and non-anodized. The use of aluminum cookware for cooking offers a significant route for the entrance of aluminum metal into food and subsequently into humans that consume such foods. There is a growing concern of the absorption of aluminum and other metals from cookware as the potential of aluminum and other metals to leach into food has been reported in cooking utensils due to factors such as temperature, $\mathrm{pH}$, duration of cooking and the presence of complexing agents from the alloys used in making the aluminum cookware. The reported high concentrations of metals like lead and arsenic leached into food is a potential health hazard that should be researched. However, the process of anodization and coating of aluminum cookware with plastic material can minimize leaching of these metals into cooked foods but nonetheless gets worn out by scratching as time goes on.

\section{Author Contributions}

Conception: $[\mathrm{AOA}]$

Design: [AOA]

Execution: [AOA, YMA]

Interpretation: [AOA, YMA]

Writing the paper: [AOA, YMA]

\section{References}

Abubakar, H. (2011). Problems and prospects of improvisation of Aluminum pot in Potiskum Area of Yobe State, Unpublished Project for the award of NCE Certificate, Fine and applied Art Department Umar Suleiman College of Education Gashu'a, Yobe State.

Adelkhani, H., Nasoodi, S., and Jafari, A. H. (2009). A study of the morphology and optical properties of electropolished aluminum in the Vis-IR region, International Journal of Electrochemical Science, 4; 238246.

Agarwal, P., Srivastava, S., Srivastava, M. M., Prakash, S., and Ramanamurthy, M. (1997). Studies on leaching of $\mathrm{Cr}$ and $\mathrm{Ni}$ from stainless steel utensils in certain acids and in some Indian drinks, Science of Total Environment, 199; 271-275.

Agency for Toxic Substances and Disease Registry (ATSDR), Division of Toxicology. (1999). ATSDR Toxicological Profile for Cadmium.
Agency for Toxic Substances and Disease Registry, US Department of Health and Human Services, Atlanta. pp 1-440.

Aleksandra, D., and Urszula, B. (2008). The impact of Nickel on human health, Journal of Elementology, 13(4); 685-696.

Al Juhaiman, L. A. (2010). Estimating Aluminum leaching from Aluminum cook wares in different meat extracts and milk, Journal of Saudi Chemical Society, 14; 131-137.

Al Juhaiman, L. A. (2012). Estimating aluminum leaching from aluminum cookware in different vegetable extracts, International Journal of Electrochemical Science, 7; 7283-7294.

Al Juhaiman, L. (2016). Curcumin Extract as a Green Inhibitor of Leaching from Aluminum Cookware at Quasi-Cooking Conditions, Green and Sustainable Chemistry, 6; 57-70. doi: $10.4236 /$ gsc. 2016.62005 .

Al Zubaidy, E. A., Mohammad, F. S., and Bassioni, G. (2011). Effect of pH, salinity and temperature on aluminum cookware leaching during food preparation, International Journal of Electrochemical Science, 6(12); 6424-6441.

Amarasooriya, A. A., and Dharmagunawardhane, H. A. (2014). Leaching of Aluminum and its Incorporation to Rice During Cooking Under Different Fluoride Concentrations in Water. SAITM Research Symposium on Engineering Advancements, 3; 213-219.

Bassioni, G., Mohammed, F. S., Al Zubaidy, E., and Kobrsi, I. (2012). Risk Assessment of Using Aluminum Foil in Food Preparation. International Journal of Electrochemical Science, 7; 4498-4509.

Berg, T., and Petersen, A. (2000). The release of nickel and other trace elements from electric kettles and coffee machines, Food Additives and Contamination, $17 ; 189-196$.

Bergkvist, C., Kippler, M., Hamadani, J. D., Grander, M., Tofail, F., and Berglund, M. (2010). Assessment of early-life lead exposure in rural Bangladesh, Environmental Research, 110; 718-724.

Cabrera, C., Lloris, F., Gimenez, R., Olalla, M., and Lopez, C. (2003). Mineral content in legume and nuts: Contribution to the spanish dietary intake, Science of Total Environment, 308; 1-14.

Caroli, F., Torre, L. A., Petrucci, F., and Violante, N. (1996). Element speciation in Bioinorganic chemistry, edited by Sergio Caroli, Chemical analysis Series, $135 ; 445-463$.

Chen, X., Zhu, G., Jin, T., and Gu, S. (2009). Effects of Cadmium on Forearm Bone Density after Reduction of Exposure for 10 years in a Chinese population, Environment International, 38(8); 1164-1168.

Chinoy, J., Sorathia, P., and Jhala, D. (2005). Flouride + Aluminum induced toxicity in mice testis with giant cells and its reversal by vitamin C, Journal of Fluoride, 38(2); 109-114.

Clark, C. S., Rampal, K. G., Thuppil, V., Roda, S. M., Succop, P., and Menrath, W. (2009). Lead levels in nem enamel household paints from Asia, Africa and South America, Environmental Research, 109; 930936.

Clark, C. S., Spenranskaya, O., Brosche, S., Gonzalez, H., Solis, D., and Kodeih, N. (2015). Total lead concentration in new decorative enamel 
paints in Lebanon, Paraguay and Russia. Environmental Research, 138; 432-428.

Codex Alimentarius Commission (CAC). (1995). Codex general standard for contaminants and toxins in foods. Joint FAO/WHO Food standards Programme, Doc. no. CX/FAC 96/17; pp. 1-44.

Dabonne, S., Koffi, B. P. K., Kouadio, E. J. P., Koffi, A. G., Due, E. A., and Kouame, L. P. (2010). Traditional Utensils: Potential Sources of Poisoning by Heavy Metals, British Journal of Pharmacology and Toxicology, 1(2); 90-92.

Deepa, P., and Padmalatha, R. (2013). Corrosion behavior of 6063 alluminium alloy in acidic and in alkaline media, Arabian Journal of Chemistry, 5; 1878-5352.

El Desoky, G. E., Aboul-Soud, M. A., Al-Othman, Z. A., Habila, M., and Giesy J. P. (2013). Seasonal Concentration of Lead in Outdoor and Indoor dust and blood of Children in Riyadh, Saudi Arabia, Environmental Giochemistry and Health, 36; 538-593.

Elinder, C. G. (1986). Zinc. In: Friberg L., Nordberg G. F., Vouk V. B. Hand book on the toxicology of metals. Second edition. Elsevier, Amsterdam, New York, Oxford; pp 23-64.

Exley, C., Korchazhkina, O., Job, D., Strekopytov, S., Polwart, A., and Crome, P. (2006). Non-invasive therapy to reduce the body burden of aluminum in Alzheimer's disease, Journal of Alzheimer's disease, 10(17); 24-29. 10.3233/JAD-2006-10103

Goyer, R. A. (1986). Toxic effect of metals. In:Casarett and Doull's Toxicology. The basic science of poisons. Third edition. p. 582-635.

Guidetti, R., and Simonetti, P. (2000). Materials for cooking. In: A guide to professional cookware, S.A.P.S. Edition 4.0; pp. 16-29.

Hassan, M. F., Sadek, M. A., Abd-El-Razik, F. H., and Kamel, E. A. (2008). Risk of aluminum toxicity and its relation to some biochemical changes in healthy, diabetic and hyperlepidemicrats, Egyptian Journal of Natural Toxins, 5(1-2); 100-120.

Kalra, V., Sahu, J. K., Bedi, P., and Pandey, R. M. (2013). Blood lead levels among school children after phasing-out of leaded petrol in Delhi, India. Indian Journal of Paediatrics, 80; 636-640.

Kapitsinou, A., Souldatou, A., Tsitsika, A, Kossiva, L., Tsentidis, C., and Nisianakis, P. (2015). Risk factors for elevated blood lead levels among Children aged 6-36months living in Greece, Child care Health Development, 41; 1199-1206.

Karbouj, R. (2007). Aluminium leaching using chelating agents as compositions of food, Food and Chemical Toxicology, 45; 1688-1693.

Kim, M. S. (2001). Aluminum exposure: a study of an effect on cellular growth rate, Science of Total Environment, 278; 127-135.

Krewski, D., Yokel, R. A., Nieboer, E., Borchelt, D., Cohen, J., Harry, J., Kacew, S., Lindsay, J., Mahfouz, A. M., and Rondeau, V. (2007). Human health risk assessment for aluminium, aluminium oxide, and aluminium hydroxide, Journal of Toxicology and Environmental Health B Critical Review, 10(1); 1-269.

Liangbo, Z., Hongfei, R., Zhuoran, W., Fenghua, W., Jianing, F., Kaili, L., and Xingquan, L. (2017). Migration law of lead and cadmium from
Chinese pots during the cooking process, International Journal of food properties, 20(3); S3301-S3310.

Malluche, H. H. (2002). Aluminum and bone disease in chronic renal failure, Nephrology Dial Tranplant, 172(2); 21-24.

Mohammad, F. S., AlZubaidy, E. A. H., and Bassioni, G. (2011). Effect of aluminum leaching process of cooking wares on food, International Journal of Electrochemical Science, 6(1); 222-230.

Nordberg, G., Nogawa, K., Nordberg, M., and Friberg, L. (2007). Cadmium. In: Handbook on toxicology of metals. L editors New York: Academic Press,. p. 65-78.

Nordic Council of Ministers (NCM) (2003). Cadmium Review. CRL, EHN Report 1, Issue no 04.

Nordic Council of Ministers (NCM) (2003). Copper Review. CRL, EHN Report 1, Issue no 04.

Nordic Council of Ministers (NCM) (2003). Lead Review. CRL, EHN Report 1, Issue no 04

Nriagu, J. O., and Azcue, J. M. (1990). Food contamination with arsenic in the environment, Advances in Environmental Science and Technology, 23; 121-143.

Odularu, A. T., Ajibade, P. A., and Onianwa, P. C. (2013). Comparative Study of Leaching of Aluminium from Aluminium, Clay, Stainless Steel, and Steel Cooking Pots, Hindawi Publishing Corporation ISRN Public Health, 3(13); 1-4.

Ogidi, M., Sridhar, M. K. C., and Coker, A. O. (2017). A Follow-Up Study Health Risk Assessment of Heavy Metal Leachability from Household Cookwares, Journal of Food Science and Toxicology, 1(1); 3.

Oke, A. G., and Oyeniyi, A. Y. (2013). Forged Aluminum Pot Production as a Vocation and Its Economic Impetus, Mediterranean Journal of Social Sciences, 4(12); 61-65.

Okunna, E. (2004). Traditional Pottery practice in contemporary Nigeria. Nigeria Craft and Technique Nigeria Craft Forum. Industrial Design Programme FUTA Akure, 1(2); 23-26.

Osborn, E. I. (2009). Casting aluminum cooking pots: labour, migration and artisan production in West africa's informal sector, 1945-2005. African Identities, 7; 373-386.

Pandey, G., and Jain, G. C. (2015). Assessment of Molybdenum induced alteration in oxidative indices, Biochemical parameters and sperm quality in Testis of Wistar male rats, Asian Journal of Biochemistry, $10(6) ; 267-280$.

Patricia, A. P. (2000). Metals and Minerals. In: U.S. Geological Survey Minerals Yearbook, USGS Publications, 1; pp.6.

Polizzi, S., Pira, E., Ferrara, M., Bugiani, M., Papaleo, A., Albera, R., and Palmi, S. (2002). Neurotoxic effects of aluminium among foundary workers and Alzheimer's disease, Neurotoxicology, 23(6); 761-774.

Ranaua, R., Oehlensclager, J., Steinhart, H. (2001). Aluminum levels of fish filet baked and grilled in Aluminum foil, Food Chemistry, 73; 1-6. 
Rignell-Hydbom, A., Skerfving, A., Lundh, T., Lingh, C., Elmstahl, S., Bjellerup, P., Junsson, B., Strumberg, U., and Akesson, A. (2009). Exposure to cadmium and persistent organochlorine pollutants and its association with bone mineral density and markers of bone metabolism on postmenopausal women, Environmental Research, 109(8); 991-996.

Salamone, J. C. (1996). Bioerodible Polymers. In: The Polymeric Materials Encyclopedia: Synthesis, Properties and Applications (Ed). CRC Press: Boca Raton, FL, USA, 4(3); pp. 732-756.

Scheirs, J. (1997). Modern Fluoropolymers. In: Modern Polyesters: Chemistry and Technology of Polyesters and Copolyesters. Wiley, New York, pp. 435-485.

Schlesinger, M. E. (2006). The Recycling Industry. In: Aluminum Recycling. CRC Press, USA; pp. 248-282. ISBN 978-0-8493-9662-5

Sekheta, M. A. F., Sahtout, A. H., Ahmad, H. F., Sekheta, A. H. F., Sharabi, R. O., Airoud, K. A. (2010). The group of hidden hazards in enhanced HACCP and ISO-22000 based quality systems, Internet Journal of Food Safety, 12: 146-157.

Semwal, A. D., Padmashree, A., Khan, M. A., Sharma, G. K., and Bawa, A. S. (2006). Leaching of aluminium from utensils during cooking of food, Journal of the Science of Food and Agriculture, 86(14); 2425-2430.

Smart, B. E., Feiring, A. E., Krespan, C. G., Yang, Z. Y., Hung, M. H., Resnick, P. R., Dolbier, W. R., and Jr. Rong, X. X. (1995). New industrial fluoropolymer science and technology, Macromolecule Symposia, 98(2); 753-767.

Soni, M. G., White, S. M., Flamm, W. G., and Burdock, G. A. (2001). Safety evaluation of dietary Aluminum, Regulatory Toxicology and Pharmacology, 33(1); 66-79.

Suleiman, M. (2011). Improvisation of Equipment for Aluminum pot Production in Fine and Applied Art Umar Suleiman College of Education, Gashu'a. Unpublished project for the award of NCE Certificate.

Sunderman, F. W., Jr. Hopfer, S. M., Sweeney, K. R., Marcus, A. H., and Most, B. M. (1989). Nickel absorption and kinetics in human volunteers, Proceedings of the Society of Experimental Biology and Medicine, 191; 5-11.

Tabrizi, A. B. (2007). Effects of Aluminium Leaching Process of Cooking Wares on food, Food Chemistry, 100; 1698-1703.

The Epoch Times. (2017). Scrap metal Pots an unrecognized source of Lead poisoning. Retrieved on 12.06.2019 from https://www.theepochtimes.com/cooking-pots-made-from-recycledmetal-a-source-of-lead-poisoning 2215631.html

Turhan, S. (2006). Aluminum Contents in Baked Meats Wrapped in Aluminium Foil, Meat Science, 74; 644-647.

Uddin, R., and Huda, N. H. (2011). Arsenic poisoning in Bangladesh, Oman medical Journal, 26; 207.

Wagner, L. (1999). Mechanical surface treatments on titanium, aluminium and magnesium alloys, Materials Science and Engineering, A263; 210-216.

Weidenhamer, J. D., Kobunski, P. A., Kuepono, G., Corbin, R. W., Gottesfeld, P. (2014). Lead exposure from aluminum cookware in Cameroon, Science of Total Environment, 469; 339-347.

Weidenhamer, J. D., Meghann, P. F., Alison, M. B., Peter, A. K., Michael, R. H., Rebecca, W. C., and Gottesfeld, P. (2016). Metal exposures from aluminum cookware: An unrecognized Public health risk in developing countries, Science of Total Environment, 542; 235-243.

World Health Organization (WHO). (1995). Inorganic Lead. International Programme on Chemical Safety. Environmental Health Criteria. Available from

http://www.inchem.org/documents/ehc/ehc/ehc194.htm (accessed 03.12.19).

World Health Organization (WHO). (2011a). Arsenic in drinkingwater. Background document for development of WHO guidelines for drinking-water quality. Available from http://www.who.int/water sanitation health/dwq/chemicals/arseni c.pdf (accessed 03.12.19).

World Health Organization (WHO). (2011b). Evaluation of certain Food Additives and Contaminants: Seventy-Fourth Report of the Joint FAO/WHO Expert committee on Food Additives (WHO Technical Report series no, 966) Available from http://whqlibdoc.who.int/trs/WHO TRS 966 eng.pdf_Caccessed 03.12.19).

Yokel, R. A., and McNamara, P. J. (2001). Aluminum Toxicokinetics: an updated minireview, Pharmacology and Toxicology, 88; 159-167.

Yousef, M. I., Kamel, K. I., El-Guendi, M. I., and El-Demerdash, F. M. (2007). An in vitro study On reproductive toxicity of aluminium chloride on rabbit sperm: the protective role of some antioxidants, Toxicology, 239; 213-223. 